\title{
PROFILAKTYKA I LECZENIE RAKA ŻOŁĄDKA - AKTUALNY PROBLEM INTERDYSCYPLINARNY
}

\section{PREVENTION AND TREATMENT OF GASTRIC CANCER - A CURRENT INTERDISCIPLINARY PROBLEM}

\author{
Bartłomiej Strzelec ${ }^{1}$, Martyna Stuła ${ }^{1}$, Piotr Chmielewski ${ }^{2}$, Renata Taboła ${ }^{1}$ \\ ${ }^{1}$ Katedra i Klinika Chirurgii Przewodu Pokarmowego i Chirurgii Ogólnej \\ Uniwersytet Medyczny im. Piastów Śląskich we Wrocławiu \\ ${ }^{2}$ Zakład Anatomii Prawidłowej, Katedra Morfologii i Embriologii Człowieka \\ Uniwersytet Medyczny im. Piastów Śląskich we Wrocławiu
}

DOI: https://doi.org/10.20883/pielpol.2018.23

\section{STRESZCZENIE}

Rak żołądka stanowi bardzo duże wyzwanie dla służby zdrowia i wymaga wielodyscyplinarnego podejścia, gdyż wczesna diagnoza i szybka interwencja chirurgiczna odgrywają ważną rolę w zmniejszeniu śmiertelności. Nowotwór ten jest piątym najczęstszym rakiem na świecie i zajmuje trzecie miejsce pod względem przyczyn zgonów na nowotwory złośliwe. Obecnie radykalna resekcja z limfadenektomią jest najważniejszym i jedynym potencjalnie skutecznym sposobem leczenia, podczas gdy chemioterapia i radioterapia mają znaczenie w terapii wspomagającej. Zakres resekcji żołądka i limfadenektomii zależy przede wszystkim od zaawansowania miejscowego nowotworu, ale także od jego typu histologicznego. Operację wykonuje się metodą laparoskopową z użyciem 4 lub 5 trokarów albo metodą klasyczną. W obu przypadkach ciągłość przewodu pokarmowego odtwarzana jest najczęściej metodą z użyciem pętli Roux en Y, natomiast metoda Bilroth II jest rzadziej stosowana, a tylko w niektórych przypadkach wykorzystuje się metodę Bilroth I. Wraz ze wzrostem doświadczenia i poprawą jakości sprzętu liczba operacji metodą laparoskopową znaczne wzrosła. Zainteresowanie laparoskopią jest coraz większe, ponieważ zabiegi te cechują się mniejszą inwazyjnością niż metoda klasyczna. Ponadto metoda laparoskopowa zapewnia wystarczające bezpieczeństwo onkologiczne i wiąże się z mniejszą liczbą powikłań pooperacyjnych i śródoperacyjnych, szczególnie u pacjentów obciążonych i starszych. Należy podkreślić, że wybór metody klasycznej, która jest standardem postępowania leczniczego w wielu krajach, nie jest błędem, lecz właściwą formą leczenia, zwłaszcza u pacjentów z zaawansowanym procesem nowotworowym.
\end{abstract}

SŁOWA KLUCZOWE: nowotwory żołądka, chirurgia ogólna, przegląd piśmiennictwa.

\section{Wprowadzenie}

Rak żołądka jest piątym najczęstszym rakiem na świecie i stanowi bardzo duże wyzwanie dla służby zdrowia, gdyż wymaga wielodyscyplinarnego leczenia, w którym chirurgia odgrywa nadrzędną rolę [1]. Mimo że

\begin{abstract}
The multidisciplinary management of gastric cancer remains a major challenge to the healthcare system as early diagnosis and timely surgical treatment are crucial for reducing the mortality rate. Gastric cancer is the fifth most common type of cancer and the third cause of cancer deaths worldwide. Currently, gastrectomy with lymphadenectomy is the most important and the only potentially effective form of treatment, while chemotherapy and radiotherapy are used as adjunct methods. The range of stomach resection and lymphadenectomy depends on the histological type of cancer and the local progression of the disease. An operation is performed using a laparoscopic method with 4 or 5 trocars, or using a classical method. In both cases, the continuity of the alimentary tract is restored using Roux en $\mathrm{Y}$, whereas the Bilroth I method is less common, and the Bilroth II method is used only in some cases. With the increase in experience and improvement in equipment quality, the number of laparoscopic gastrectomies performed for gastric cancer has increased significantly. Therefore, there has been an increasing focus on this method as being less invasive compared to open gastrectomy. Moreover, the oncological safety of the laparoscopic approach has been confirmed and this method has also been shown to be associated with lower risk of complications during and following surgery, especially in older patients and individuals who are at greater risk of negative outcomes. It should be stressed that the use of the classical method, which remains a standard of treatment in many countries, is justified in patients with advanced cancer.
\end{abstract}

KEYWORDS: stomach neoplasms, general surgery, review.

zapadalność na ten nowotwór maleje, nadal stanowi on stosunkowo częstą przyczynę zgonów, nawet w krajach wysoko rozwiniętych, takich jak USA i Japonia [2, 3], w których zarówno świadomość społeczna dotycząca znaczenia zdrowego stylu życia i profilaktyki chorób 
nowotworowych, jak i metody wykrywania wczesnych form raka są na znacznie wyższym poziomie niż w naszym kraju. Szacuje się, że każdego roku w USA na ten rodzaj nowotworu zapada ponad 21 tysięcy osób, z czego 12 tysięcy umiera. Polskie analizy epidemiologiczne wskazują, iż w XX wieku dwie najistotniejsze lokalizacje, które w największym stopniu decydowały o zagrożeniu nowotworami złośliwymi w Polsce, to płuca i żołądek, zwłaszcza w przypadku mężczyzn, tak więc historycznie rak żołądka był częstym nowotworem w populacji polskiej i jedną z najczęstszych przyczyn zgonów na raka. W XXI wieku na 100 tysięcy mężczyzn 23 osoby chorują na raka żołądka w ciągu roku, podczas gdy u kobiet ten współczynnik zachorowań wynosi 8/100 tys./rok. Zapadalność na raka żołądka, jak na wiele innych rodzajów nowotworów, rośnie istotnie z wiekiem. Ryzyko tej choroby jest znacznie większe u osób starszych, zwłaszcza po 50. roku życia i ponad $75 \%$ chorych ma co najmniej 50 lat. Wczesne postawienie trafnej diagnozy i szybka interwencja chirurgiczna są najważniejsze z punktu widzenia sukcesu terapeutycznego, lecz niezwykle trudne ze względu na nieznaczne i nieswoiste wczesne objawy choroby, które są albo lekceważone przez chorych, albo uznawane za objawy choroby wrzodowej, przez co rak rozpoznawany jest często w późnych etapach zaawansowania. W konsekwencji operacja przeprowadzana jest w późnym stadium, przez co szansa na 5-letnie przeżycie po operacji jest mała [4]. Zabieg operacyjny to jedyny potencjalnie skuteczny sposób leczenia, natomiast radioterapia i chemioterapia zwiększają szansę na wyleczenie i mają znaczenie w terapii wspomagającej [5-11]. Tak więc chirurgia jest niewątpliwie najważniejszym elementem leczenia raka żołądka, a jej aspekty zasługują na szczególną uwagę i zostaną bardziej szczegółowo przedyskutowane w dalszej części artykułu. Po przedstawieniu najważniejszych informacji dotyczących profilaktyki i etiologii skoncentrujemy się na omówieniu wybranych technik chirurgicznych oraz krótkiej charakterystyce porównawczej metody laparoskopowej i klasycznej na podstawie przeglądu aktualnego piśmiennictwa z zakresu chirurgii raka żołądka.

\section{Etiologia, patofizjologia i profilaktyka raka żołądka}

Etiologia raka żołądka jest wieloczynnikowa, aczkolwiek za karcynogen pierwszego rzędu powszechnie uważa się Helicobacter pylori. Według danych Światowej Organizacji Zdrowia (WHO) przewlekłe zakażenie tą gram-ujemną proteobakterią dotyczy co najmniej $50 \%$ osób w krajach rozwijających się (lub nawet $80 \%$ ) i około $30 \%$ w krajach rozwiniętych. Do innych ważnych czynników ryzyka należy zaliczyć przede wszystkim: autoimmunologiczne zanikowe zapalenie żołądka, różne czynniki genetyczne, polipy gruczolakowate, rodzinną polipowatość żołądka, chorobę Menetriera, czynniki ryzyka związane z wykonywanym zawodem (m.in. sadze, smoły, różne rakotwórcze produkty spalania, dioksyny), używki (alkohol, palenie tytoniu) oraz niewłaściwą dietę i sposób odżywiania się, m.in. zbyt duże spożycie soli kuchennej, spożycie pokarmów głęboko przetworzonych, solonych, wędzonych, grillowanych, peklowanych, konserwowanych, zawierających groźne substancje toksyczne i rakotwórcze, takie jak aflatoksyny, dioksyny, benzopireny, azotany, lub potencjalnie rakotwórcze, takie jak akroleina, która powstaje podczas podgrzewania łłuszczów, a także zbyt mała ilość świeżych warzyw i owoców zawierających naturalne witaminy i przeciwutleniacze (Tabela 1). Warto pamiętać, że choć stosowanie wielu sztucznych konserwantów chroni żywność przed zepsuciem, to jednak ze spożytych azotanów w środowisku żołądka i na skutek działania występujących w nim bakterii powstają rakotwórcze $\mathrm{N}$-nitrozozwiązki. Smażenie, pieczenie, wędzenie czy grillowanie mięsa i innych produktów wiąże się z powstawaniem dużych ilości potencjalnie rakotwórczych związków (m.in.: akroleina, wielopierścieniowe węglowodory aromatyczne i inne). Również środki ochrony roślin, takie jak pestycydy, zawierają te szkodliwe i niebezpieczne związki. Częste ich występowanie w diecie, zwłaszcza jeśli towarzyszy temu spożywanie alkoholu, który choć jest słabym mutagenem, to może wielokrotnie zwiększać ryzyko mutacji, jeśli jest przyjmowany wraz z innymi silnymi mutagenami (np. pochodzącymi z dymu tytoniowego) na zasadzie synergii. Należy więc stosować zrównoważoną, urozmaiconą i zdrową dietę, bogatą w błonnik i naturalne witaminy i przeciwutleniacze, a unikać tych czynników ryzyka, co jest jednak trudnym wyzwaniem we współczesnych czasach. Bardzo liczne produkty spożywcze, sztuczne i naturalne, zwierają duże ilości konserwantów i innych środków chemicznych. Warto uświadomić sobie, że zwykłe jabłko, które wydaje się produktem zdrowym i bezpiecznym (w języku angielskim istnieje nawet powiedzenie: An apple a day keeps the doctor away), jest wielokrotnie opryskiwane trującymi i szkodliwymi środkami chemicznymi ochrony roślin, zanim trafi do sprzedaży. Nie należy z tego powodu rezygnować ze spożywania świeżych warzyw i owoców, ale dobrze jest pamiętać, że konieczne jest jak największe urozmaicenie diety i niespożywanie jednego rodzaju pokarmu, a także spożywanie dużych ilości naturalnego błonnika, witamin czy przeciwutleniaczy. Wielu autorów zauważa, że zdrowa, naturalna i mająca duży potencjał ochronny dieta, która stanowi też jeden z podstawowych elementów profilaktyki przeciwnowotworowej, jest w praktyce trudna do realizacji, ale konieczna, gdyż może zapewniać skuteczną ochronę przed chorobami nowotworowymi. 
Tabela 1. Czynniki ryzyka związane z rozwojem raka żołądka Table 1. Risk factors associated with the development of gastric cancer

\begin{tabular}{c} 
Czynniki ryzyka/Risk factors \\
\hline $\begin{array}{c}\text { Przewlekłe zakażenie Helicobacter pylori/ } \\
\text { Chronic Helicobacter pylori infection }\end{array}$ \\
Narażenia zawodowe i związane ze stylem życia/ \\
Occupational and lifestyle-related exposures \\
Palenie papierosów/ \\
Cigarette smoking
\end{tabular}

Źródło: opracowanie własne

Source: author's own analysis

Obecnie uważa się, że istnieje też wiele niepoznanych jeszcze czynników predysponujących do rozwoju raka żołądka. Rola czynników genetycznych jest niepodważalna, gdyż w piśmiennictwie naukowym opisano całe rodziny chore na ten rodzaj nowotworu, w których rozsiane zmiany nowotworowe wiązano z mutacjami genu dla E-kadheryny. Ryzyko raka jest też podwyższone w przypadku krewnych pierwszego stopnia osób chorych.

Jednak zdecydowanie najlepiej udokumentowana i naukowo potwierdzona jest rola przewlekłego zakażenia Helicobacter pylori. Bakteria ta dzięki mechanizmom przystosowawczym do życia w niskim pH może przebywać w nieprzyjaznym środowisku żołądka przez kilka dekad. W tym czasie wpływa m.in. na funkcjonowanie błony śluzowej. Stopniowo zmienia się przyleganie do siebie komórek śluzówki żołądka, ich polarność oraz organizacja i funkcjonowanie cytoszkieletu. Ponadto dochodzi do wydzielania wielu cytokin prozapalnych i czynników stymulujących proliferację komórek żołądka. W efekcie tych zmian rozwija się stan zapalny, który prowadzi do uszkodzeń strukturalnych i funkcjonalnych błony śluzowej i innych warstw ściany żołądka oraz zmian mikrośrodowiska pod względem profilu hormo- nalnego i enzymatycznego. Zakażenie początkowo powoduje powierzchowne zapalenie błony śluzowej, które poprzez zapalenie zanikowe doprowadza do zniszczenia śluzówki. W dalszej kolejności obserwuje się zmiany o charakterze metaplazji, a następnie dysplazji. Końcowym efektem tych przemian jest rak żołądka. Ze względu na istotną rolę tej bakterii w etiopatogenezie raka żołądka, jeśli jest to możliwe, zaleca się jej eradykację przed operacją.

W profilaktyce raka żołądka decydujące znaczenie mają zdrowa dieta, właściwe odżywianie się i styl życia (m.in. duża ilość świeżych warzyw i owoców oraz unikanie wszystkich wymienionych powyżej czynników ryzyka), a przede wszystkim „czujność onkologiczna” i nadzór u osób o podwyższonym ryzyku (np. zakażonych Helicobacter pylori, krewnych pierwszego stopnia osób chorych, pacjentów, u których występują pewne objawy sugerujące chorobę wrzodową, ze względu na niespecyficzność objawów raka).

Pierwsze objawy są nieznaczne i niecharakterystyczne lub nawet choroba rozwija się bezobjawowo. Początkowo objawy są bardzo podobne do choroby wrzodowej, a więc są to dyskomfort, niestrawność, niewielki ból w nadbrzuszu (u większości chorych), nieznaczna utrata masy ciała i osłabienie, nudności, wzdęcia czy w końcu dysfagia (jako objaw zamknięcia przejścia przełykowo-żołądkowego). W późnych etapach choroby objawy stają się nieco bardziej charakterystyczne i obejmują uczucie wczesnej sytości i brak apetytu (szczególnie wstręt do pokarmów mięsnych), wymioty, smoliste stolce, wyniszczenie, dalszą utratę masy ciała oraz objawy wynikające z przerzutów, jak np. wodobrzusze, żółtaczka czy złamania kości.

W tej sytuacji rolą lekarza jest zebranie bardzo szczegółowego wywiadu w kierunku obciążenia rodzinnego, narażeń zawodowych oraz wynikających z diety, odżywiania się i stylu życia. Należy zauważyć, że u chorych z rakiem żołądka, szczególnie w przypadku niezaawansowanego jeszcze nowotworu, objawy zgłaszane przez pacjenta będą wydawały się lekarzowi błahe, co jest jednym z tych problemów, który poważnie utrudnia wczesne postawienie trafnej diagnozy i podjęcie skutecznego leczenia, a jest to jedyna szansa na ocalenie życia chorego, gdyż rak żołądka to choroba podstępna i wyjątkowo agresywna, w której nawet wczesne wykrycie i szybka interwencja chirurgiczna nie gwarantują wyleczenia.

\section{Kliniczna i histologiczna klasyfikacja raka żołądka}

Współcześnie dostępnych jest wiele możliwości terapeutycznych i sposobów leczenia raka żołądka [12-20], a kluczowa sprawa to wykonanie radykalnego zabiegu 
usunięcia nowotworu we wczesnych etapach choroby. Metoda leczenia zależy przede wszystkim od zaawansowania choroby i wybierana jest w oparciu o aktualnie obowiązujące w danym kraju wytyczne i standardy dotyczące postępowania leczniczego.

Pod względem anatomicznym żołądek jest podprzeponowo i wewnątrzotrzewnowo położonym narządem jamy brzusznej o dobrym unaczynieniu, które pochodzi z czterech głównych tętnic przebiegających wzdłuż krzywizny mniejszej i większej oraz licznych mniejszych naczyń zaopatrujących dno i wpust. Tętnice unaczyniające żołądek pochodzą od pnia trzewnego i jego gałęzi i są to m.in. tętnice żołądkowe lewa (bezpośrednia gałąź pnia trzewnego) i prawa (gałąź t. wątrobowej właściwej) oraz tętnice żołądkowo-sieciowe lewa (gałąź t. śledzionowej) i prawa (gałąź t. żołądkowo-dwunastniczej). Węzły chłonne drenujące chłonkę z żołądka zostały przyporządkowane do trzech głównych grup (N1-N3) według JGCA (Japanese Gastric Cancer Association). Węzły chłonne okołowpustowe, przyoddźwiernikowe oraz położone wzdłuż krzywizny większej i mniejszej należą do grupy N1. Wzdłuż tętnicy żołądkowej lewej, wątrobowej wspólnej, śledzionowej, wątrobowej właściwej i w okolicy pnia trzewnego położone są węzły grupy N2. Grupa N3 zlokalizowana jest zaotrzewnowo w okolicy wielkich naczyń jamy brzusznej.

Istnieje wiele różnych klasyfikacji dotyczących raka żołądka. Pod względem klinicznym wyróżnia się raka wczesnego (ang. early gastric cancer - EGC) i zaawansowanego (ang. advanced gastric cancer - AGC). EGC jest zmianą ograniczoną do błony śluzowej i warstwy podśluzowej, niezależnie od obecności przerzutów w węzłach chłonnych [21]. AGC jest zmianą, która przekracza warstwę podśluzową, naciekając dalsze warstwy (błonę mięśniową i surowiczą), a w kolejnym etapie sąsiednie narządy. EGC na skutek płytszego naciekania wiąże się z lepszym rokowaniem.

Natomiast spośród histologicznych klasyfikacji najbardziej przydatny w praktyce jest podział zaproponowany przez Laurena, w którym wyróżnia się dwa typy: Lauren 1 i Lauren 2. Histologiczny typ nowotworu ma znaczenie dla rokowania, a jego określenie jest przydatne przy podejmowaniu decyzji pod względem zakresu resekcji i limfadenektomii. Typ 1, morfologicznie podobny do błony śluzowej jelita, wiąże się z lepszym rokowaniem niż typ 2 , tj. rozlany o małej kohezji komórek nowotworowych i niezaznaczonych granicach nacieku. Oprócz tych dwóch znanych od wielu lat typów wyróżniono niedawno jeszcze jeden, tj. rak mieszany żołądka [22]. Jest on nowo zdefiniowanym histologicznym typem raka, który w klasyfikacji WHO pojawił się w 2010 roku. Składa się on z komórek o morfologii charakterystycznej dla raka gruczołowego (Lauren 1) i raka rozlanego (Lauren 2). W stawianiu diagnozy i ocenie rokowania dla raka żołądka przydatne może być określenie stężenia markerów nowotworowych. CA 19-9 jest związany z przerzutami do węzłów chłonnych, a jego wartość zazwyczaj zwiększa się wraz z liczbą zajętych węzłów chłonnych. Ponadto przedoperacyjna wartość tego wskaźnika może być wykorzystana do określenia ryzyka wystąpienia mikroprzerzutów, a zatem także hematogennego rozsiewu nowotworu u pacjentów z niezajętymi węzłami chłonnymi [23]. Należy pamiętać o ograniczonej czułości i swoistości tego testu i o tym, że wysokie stężenia CA 19-9 zazwyczaj świadczą o dużym zaawansowaniu choroby, jednak jego niskie stężenia nie gwarantują braku zaawansowania. Nawrót choroby po nieradykalnej operacji występuje zazwyczaj w ciągu 2 lat i najczęściej szybko prowadzi do śmierci [2].

\section{Podstawy techniki operacyjnej i krótki rys historyczny}

Pierwsza subtotalna resekcja żołądka metodą Billrotha została wykonana w 1881 roku. Zapoczątkowała ona erę chirurgii tego narządu. George Schlatter w 1897 roku jako pierwszy na świecie wykonał gastrektomię u pacjenta z rakiem żołądka, co można uznać za kamień milowy w chirurgii tego narządu [24]. W USA jako pierwszy dokonał tego Brigham w 1898 roku [15]. Od tego czasu technika klasycznej gastrektomii (ang. classic gastrectomy, open gastrectomy - OG) rozwijała się i była stopniowo udoskonalana, a obecnie jest jedną z podstawowych metod leczenia.

Resekcja żołądka metodą laparoskopową jest techniką znacznie nowszą od klasycznej. Pierwsze operacje tą metodą przeprowadzono we wczesnych latach 90. XX wieku. Interesujące jest, że wielu chirurgów w krajach wschodniej Azji, takich jak Japonia i Korea Południowa, preferuje właśnie tę metodę leczenia [25, 26]. W przypadku raka typu Lauren 2 (linitis plastica), w związku z jego agresywnym przebiegiem i niekorzystnym rokowaniem, a także rozległością naciekanych tkanek, niezbędne jest usunięcie całego żołądka, podczas gdy w przypadku typu Lauren 1, w zależności od zaawansowania klinicznego i położenia guza, można zdecydować się na gastrektomię lub prawie całkowitą resekcję. W przypadku raków typu Lauren 1 położonych w okolicy wpustu lub trzonu żołądka niezbędne jest wykonanie gastrektomii, podczas gdy w guzach okolicy odźwiernika (dystalny rak żołądka) zalecana jest resekcja 4/5 dystalnej części narządu z co najmniej 5-6-centymetrowym marginesem tkanek zdrowych [27, 28]. W przypadku raka typu Lauren 2 ze względu na jego bardzo agresywny i szybki rozwój oraz rozlany charakter zawsze niezbędne jest całkowite usunięcie żołądka. Mnogość występowania węzłów chłonnych w okolicy żołądka po- 
woduje, że w momencie rozpoznania raka najczęściej obserwuje się także przerzuty drogą naczyń chłonnych, przez co kluczowe w terapii jest również usunięcie węzłów chłonnych. Limfadenektomia D2, polegająca na usunięciu grup węzłów N1 i N2, od wielu lat jest standardem leczenia zarówno wczesnego, jak i zaawansowanego raka żołądka [29]. Powinna być ona rutynowo przeprowadzana w leczeniu raka żołądka, podczas gdy bardziej rozległa limfadenektomia D3, w której usuwane są wszystkie grupy węzłów chłonnych N1-N3, powinna być wykonywana u pacjentów z podejrzeniem zajęcia licznych, dalszych węzłów chłonnych [27]. W przypadku nacieku guza na ogon trzustki lub śledzionę należy oprócz limfadenektomii D2 usunąć także nacieczone tkanki w jednym bloku tkankowym. Powyżej przytoczone standardy leczenia odnoszą się zarówno do metody otwartej, jak i laparoskopowej. Niezależnie od wybranej techniki preparacja powinna być przeprowadzona ostrożnie i starannie [27], aby uniknąć nieumyślnego pozostawienia lub uszkodzenia potencjalnie zajętych węzłów chłonnych. W miarę możliwości wszystkie tkanki powinny być usunięte en bloc. Ciągłość przewodu pokarmowego odtwarzana jest najczęściej metodą z użyciem pętli Roux en Y, rzadziej metodą Bilroth II i tylko w niektórych przypadkach Bilroth I. Aby zapobiec nawrotowi choroby i zwiększyć przeżywalność pacjentów z rakiem żołądka, oprócz radykalnej operacji w wybranych przypadkach należy zastosować także terapię adiuwantową [4]. W Europie standardem bazującym na wynikach Medical Research Council Adiuvant Gastric Infusional Chemotherapy (MAGIC) trial jest okołooperacyjna chemioterapia, natomiast w USA podstawą jest chemioterapia pooperacyjna (standardowa terapia bazująca na Southwest Oncology Group 9008/Intergroup 0116 trial). Dzięki dobremu systemowi badań przesiewowych coraz więcej raków żołądka wykrywanych jest w stadium wczesnym. W Japonii ponad 50\% guzów żołądka to raki wczesne (EGC) o dobrym rokowaniu. W takich przypadkach, jeżeli chory spełnia kryteria kwalifikacji, można podjąć się leczenia endoskopowego [30]. Wskazaniami bezwzględnymi do takiego leczenia są raki gruczołowe wysoko zróżnicowane, bez cech owrzodzenia, z głębokością nacieku nieprzekraczającą błony śluzowej i o wymiarze poprzecznym $<2 \mathrm{~cm}$. Wskazaniami względnymi są guzy nieprzekraczające błony śluzowej, o małym prawdopodobieństwie przerzutów do węzłów chłonnych, o typie wysoko zróżnicowanym bez cech owrzodzenia i średnicy $>2 \mathrm{~cm}$ lub o typie wysoko zróżnicowanym z cechami owrzodzenia i o średnicy $<3 \mathrm{~cm}$, lub o typie nisko zróżnicowanym bez cech owrzodzenia i o średnicy $<2 \mathrm{~cm}$. Obowiązkowo przeprowadza się badanie histopatologiczne preparatu. Po zabiegu zaleca się gastroskopię po 3 i 9 miesiącach, a potem co 5 lat. Jeżeli przed zabiegiem nie przeprowadzono eradykacji $H$. pylori, należy to zrobić po leczeniu.

\section{Porównanie metody klasycznej i laparoskopowej}

Jak wspomniano wcześniej, leczenie raka żołądka jest wyjątkowo trudne i wymaga dużego doświadczenia. Mimo ustalonych wytycznych czasami ze względu na trudność jednoznacznej oceny zaawansowania procesu nie tylko wybór metody operacji i terapii uzupełniającej, ale także zakres resekcji i limfadenektomii jest niejasny. Istotne jest, by ten zakres gwarantował jednocześnie radykalność onkologiczną i minimalizację powikłań śródoperacyjnych i pooperacyjnych, co zapewni najlepszą przeżywalność pacjentów [26]. Niezależnie od wybranej metody leczenia należy zawsze pamiętać, że tylko radykalna resekcja daje szansę na wyleczenie. Oczywiście nie należy bagatelizować przydatności terapii uzupełniającej, która zastosowana zgodnie z aktualnymi wytycznymi poprawia rokowanie i zwiększa szansę na wyzdrowienie. Przykładowo neoadiuwantowa chemioterapia okazuje się skutecznym uzupełniającym leczeniem guzów pierwotnie nieoperacyjnych [4]. Pacjenci z nieresekcyjnymi rakami żołądka w badaniach Kim i wsp. [4] wykazali w 44,8\% przypadków pozytywną odpowiedź na chemioterapię już w pierwszym miesiącu leczenia, a po zakończonym cyklu $69 \%$ chorych zostało zakwalifikowanych do operacji jako pacjenci z rakiem resekcyjnym, u których gastrektomia z limfadenektomią D2 okazała się radykalna w 94,4\%. Jest to doskonały przykład interdyscyplinarnego leczenia zaawansowanego raka żołądka, pokazujący, że skojarzenie chemioterapii i chirurgii pozwala osiągnąć w wielu przypadkach pozytywne wyniki, co nie byłoby możliwe w przypadku zastosowania tylko jednej metody leczenia. Nie bez znaczenia pozostaje problem wyboru odpowiedniego zakresu limfadenektomii. Wspomniany wcześniej złoty standard leczenia polegający na rutynowym przeprowadzaniu limfadenektomii D2 pozwala uzyskać pomyślne wyniki leczenia w większości przypadków. Jednak badania Hartgrink i wsp. [31] na grupie 711 pacjentów pokazują, że korzyści z tak rozległego zabiegu jak limfadenektomia D2 mogą czerpać tylko chorzy z przerzutami do węzłów N1 i N2. Wyniki badań wskazują, że śmiertelność chorych z grupy, w której przeprowadzano limfadenektomię D1, w stosunku do grupy D2 jest znacznie mniejsza (25\% vs 43\%; $p<0,001$ ), podczas gdy w przeżyciu odległym, 11-letnim, różnice te są nieistotne statystycznie (30\% vs 35\%; $p=0,53$ ) [31]. Jednak przedoperacyjna lub nawet śródoperacyjna ocena stopnia zajęcia poszczególnych grup węzłowych jest bardzo trudna, co praktycznie uniemożliwia podział pacjentów na tych z przerzutami do węzłów N1 i tych 
z zajętymi węzłami N1 i N2. Wobec tego nie da się jednoznacznie ocenić, który chory powinien mieć przeprowadzoną limfadenektomię D2, a który - D1. Biorąc pod uwage najnowsze zalecenia i fakt, że w Polsce większość diagnozowanych raków żołądka jest w zaawansowanym stadium, wykonywanie tylko limfadenektomii D1 jest bardzo ryzykowne, a limfadenektomia D2 zgodnie z wytycznymi powinna być standardem postępowania. Wraz ze wzrostem doświadczenia i poprawą jakości sprzętu liczba operacji przeprowadzanych metodą laparoskopową znacznie wzrosła [32-36]. Jest ona często wybierana jako metoda mniej inwazyjna od klasycznej, szczególnie w przypadkach raków wczesnych. W Japonii dzięki dobremu systemowi badań profilaktycznych częstość występowania raka w stadium wczesnym to ponad 50\% [34]. Nie dziwi zatem fakt, że Japończycy dominują w chirurgii laparoskopowej, a liczba operacji tego typu wzrosła u nich dziesięciokrotnie w roku 2009 w porównaniu do poprzedniej dekady. Hur i wsp. [25] pokazują w swoich badaniach, że oprócz leczenia wczesnych raków żołądka laparoskopia jest przydatna także w leczeniu guzów w stanie zaawansowanym. Duże, wieloośrodkowe i randomizowane badania porównujące przeżywalność pacjentów z przedoperacyjnie zdiagnozowanym AGC, leczonych chirurgicznie metodą laparoskopową i klasyczną z uwzględnieniem limfadenektomii D2, nie wykazały różnic w przeżyciu 3-letnim [25]. Pacjenci operowani laparoskopowo cechowali się jednak szybszym powrotem do zdrowia po zabiegu niż pacjenci operowani w sposób klasyczny [37, 38]. Co ciekawe, niektórzy badacze [15] utrzymują, że śmiertelność jest istotnie mniejsza u pacjentów operowanych metodą laparoskopową, a u chorych operowanych metodą klasyczną częściej obserwuje się powikłania pooperacyjne. Badania Zhang i wsp. [37] przeprowadzone na dwóch równolicznych grupach pacjentów $(\mathrm{N}=86)$, z których jedna była operowana klasycznie, a druga laparoskopowo, nie wykazały istotnych różnic w przeżyciu 5-letnim (56\% vs 59\%), natomiast w przypadku metody laparoskopowej w porównaniu do klasycznej wykazano istotnie statystycznie mniejszą utratę krwi śródoperacyjnie (200 vs $260 \mathrm{ml} ; p=0,003$ ). Również czas hospitalizacji okazał się znacznie krótszy po zastosowaniu metody laparoskopowej.

Przytoczone powyżej wyniki badań faworyzują metodę laparoskopową. Należy zauważyć, że w większości są to badania naukowców japońskich, którzy ze względu na dużą częstość występowania raka żołądka w swoim kraju stali się cenionymi na świecie specjalistami od chirurgii tego narządu. Bardzo dobre wyniki leczenia laparoskopowego badaczy japońskich najpewniej uzyskano dzięki ich ogromnemu i wieloletniemu doświadczeniu w chirurgii laparoskopowej żołądka. Do powyższych badań należy podchodzić z ostrożnością, a w pozostałych krajach, gdzie ta metoda nadal nie jest rutynowo stosowana, leczenie powinno opierać się na najnowszych wytycznych obowiązujących w kraju, tym bardziej że wybór metody klasycznej nie jest błędem, tylko standardowym postępowaniem w wielu przypadkach pacjentów z zaawansowanym rakiem.

Niektóre badania wykazują wyższość metody laparoskopowej nad metodą klasyczną, szczególnie w przypadku gastrektomii wykonywanej u starszych pacjentów [39]. Tacy chorzy zazwyczaj obciążeni są licznymi chorobami współistniejącymi, co powoduje znacznie wyższą śmiertelność i wydłuża okres hospitalizacji w porównaniu z osobami młodszymi. U pacjentów w tej grupie wiekowej operacja laparoskopowa wydaje się bezpieczniejsza, gdyż jest związana z mniejszą utratą krwi i szybszym powrotem do zdrowia po operacji [39]. Nie dotyczy to oczywiście pacjentów starszych z niewydolnością krążeniowo-oddechową, u których zabiegi laparoskopowe są bezwzględnie przeciwwskazane. Metaanaliza wykonana na podstawie licznych badań opublikowanych w okresie od 1990 do 2013 roku wykazuje, że pacjenci operowani laparoskopowo cechują się również mniejszym bólem pooperacyjnym; następuje u nich także szybszy powrót perystaltyki jelit [40], co jest typowe dla laparoskopii i związane z jej mniejszą inwazyjnością. Wadą metody laparoskopowej jest dłuższy czas operacji, co wiąże się ze wzrostem kosztów leczenia, jednak krótszy czas hospitalizacji z pewnością przynajmniej częściowo rekompensuje te koszty. Powyższa metaanaliza wykazuje, że laparoskopia cechuje się takim samym bezpieczeństwem onkologicznym jak w przypadku laparotomii, więc może być ona wykorzystywana w wybranych przypadkach przez doświadczonych chirurgów w ośrodkach o wysokiej referencyjności jako alternatywa dla metody klasycznej. Podsumowując, metoda laparoskopowa zapewnia wystarczające bezpieczeństwo onkologiczne. Ponadto według przytoczonych badań wiąże się z mniejszą liczbą powikłań pooperacyjnych i śródoperacyjnych, szczególnie u pacjentów obciążonych i starszych. Należy jednak zaznaczyć, że wybór metody klasycznej to nie błąd, ale standard postępowania w wielu krajach, gdzie metoda laparoskopowa nie jest jeszcze szeroko rozpowszechniona. Ponadto metoda otwarta w niektórych przypadkach znacznego zaawansowania choroby jest jedyną racjonalną formą leczenia, która oprócz możliwości lepszej oceny wzrokowej daje chirurgowi możliwość palpacji zajętych tkanek i przeprowadzenia radykalnego zabiegu, co byłoby bardzo trudne lub niemożliwe przy użyciu laparoskopii. W naszych rozważaniach skoncentrowaliśmy się głównie na aspekcie leczenia raka typu Lauren 1, w przypadku którego w niektórych sytuacjach 
można wykonać resekcje subtotalne. Należy jednak zaznaczyć, że takie postępowanie w leczeniu raka typu Lauren 2 jest błędne i tylko gastrektomia daje choremu szanse na wyzdrowienie. W aktualnym piśmiennictwie brakuje prac oceniających skuteczność leczenia laparoskopowego w przypadku raka typu Lauren 2. Należy więc przyjąć, że z powodu niewystarczających danych tego typu nowotwory powinny być operowane w sposób klasyczny w ośrodkach wysoce wyspecjalizowanych w leczeniu raka żołądka.

\section{Wnioski}

1. Wczesna diagnoza raka żołądka jest jednym z najważniejszych czynników zwiększających szansę na przeżycie, tak więc nie należy bagatelizować nawet pozornie błahych objawów nieswoistych i w przypadku podejrzenia choroby żołądka wykonywać badania pozwalające wykluczyć raka.

2. Gastrektomia lub prawie całkowita resekcja z limfadenektomią D2 lub D3 są jedynym leczeniem dającym szansę na długoletnie przeżycie. Radioterapia i chemioterapia mają znaczenie jako terapia wspomagająca, która jednak w wielu przypadkach umożliwia wyleczenie pacjentów, u których nie byłoby to możliwe, jeśli wykorzystano by tylko jedną metodę leczenia; takie postępowanie wynika z konieczności interdyscyplinarnego leczenia raka żołądka.

3. Metoda laparoskopowa leczenia raka żołądka cechuje się taką samą radykalnością onkologiczną i 5-letnim przeżyciem pacjentów jak metoda klasyczna. Ponadto charakteryzuje się mniejszą śródoperacyjną utratą krwi, niższym nasileniem bólu pooperacyjnego i krótszym czasem hospitalizacji.

4. Przy wyborze chirurgicznej metody leczenia należy kierować się aktualnymi wytycznymi krajowymi. Metody mało inwazyjne sprawdzają się w przypadkach małego zaawansowania choroby, podczas gdy w zaawansowanym stadium metodą z wyboru jest operacja klasyczna.

\section{Piśmiennictwo}

1. Desiderio J, Jiang Z, Nguyen $\mathrm{N}$ et al. Robotic, laparoscopic and open surgery for gastric cancer compared on surgical, clinical and oncological outcomes: a multi-institutional chart review. A study protocol of the International study group on Minimally Invasive surgery for GASTRIc Cancer - IMIGASTRIC. BMJ Open. 2015; 5.

2. D'Angelica M, Gonen M, Brennan M et al. Patterns of Initial Recurrence in Completely Resected Gastric Adenocarcinoma. Ann Surg. 2004; 5: 240.

3. Yamada N, Akai A, Nomura $Y$ et al. The impact and optimal indication of non-curative gastric resection for stage
IV advanced gastric cancer diagnosed during surgery: 10 years of experience at a single institute. World J Surg Oncol. 2016; 14: 79.

4. Kim M, Lim J, Hyung W et al. Neoadjuvant chemoradiotherapy followed by D2 gastrectomy in locally advanced gastric cancer. World J Gastroenterol. 2015; 21(9): 2711-2718.

5. Choi Y, An J, Hyung W et al. Comments to young surgeons concerning laparoscopic spleen-preserving D2 lymph node dissection for advanced gastric cancer on the upper body. Chin J Cancer Res. 2014; 26(3): 231-233.

6. Fang $\mathrm{F}, \mathrm{Gao} \mathrm{J}, \mathrm{Bi} X$ et al. Effect and clinical significance of fast-track surgery combined with laparoscopic radical gastrectomy on the plasma level of vascular endothelial growth factor in gastric antrum cancer. Springerplus. 2016; 5: 50.

7. Ma Z, Bao X, Gu J. Effects of laparoscopic radical gastrectomy and the influence on immune function and inflammatory factors. Exp Ther Med. 2016; 12: 983-986.

8. Kim K, Kim M, Jung G et al. Long-Term Outcomes and Feasibilty with Laparocopy-Assisted Gastrectomy for Gastric Cancer. J Gastric Cancer. 2010; 12(1): 18-25.

9. Chen X, Wen L, Rui $Y$ et al. Long-term Survival Outcomes of Laparoscopic Versus Open Gastrectomy for Gastric Cancer: A Systematic Review and Meta-analysis. Medicine. 2015; 94(4).

10. Zou Z, Zhao L, Mou T et al. Laparoscopic vs open D2 gastrectomy for locally advanced gastric cancer: A meta-analysis. World J Gastroenterol. 2014; 20(44): 16750-16764.

11. Caruso S, Patriti A, Roviello F et al. Laparoscopic and robotassisted gastrectomy for gastric cancer: Current considerations. World J Gastroenterol. 2016; 22(25): 5694-5717.

12. Brenkman H, Haverkamp L, Ruurda J et al. Worldwide practice in gastric cancer surgery. World J Gastroenterol. 2016; 22(15): 4041-4048.

13. Im W, Kim M, Ha T et al. Tumor Size as a Prognostic Factor in Gastric Cancer Patient. J Gastric Cancer. 2012; 12(3): 164-172.

14. Kang S, Lee S, Kim C et al. Comparison of Learning Curves and Clinical Outcomes between Laparoscopy-assisted Distal Gastrectomy and Open Distal Gastrectomy. J Gastric Cancer. 2010; 10(4): 247-253.

15. Higgins R, Kubasiak J, Jacobson R et al. Outcomes and Use of Laparoscopic Versus Open Gastric Resection. JSLS. 2015; 4: 19.

16. Burdan F, Zinkiewicz K, Szumiło J et al. Anatomical classification of the shape and topography of the operated stomach. Folia Morphol. 2012; 71(3): 129-135.

17. Tanizawa Y, Terashima M. Lymph node dissection in the resection of gastric cancer: review of existing evidence. Gastric Cancer. 2010; 13: 137-148.

18. Schubert M. Functional anatomy and physiology of gastric secretion. Curr Opin Gastroenterol. 2015; 31(6): 479-485.

19. Hunt R, Camilleri M, Crowe $S$ et al. The stomach in health and disease. Gut. 2016; 64: 1650-1668.

20. Mihmanli M, Ilhan E, Idiz U et al. Recent developments and innovations in gastric cancer. World J Gastroenterol. 2016; 22(17): 4307-4320.

21. Zheng $Z$, Zhang $Y$, Zhang $L$ et al. A nomogram for predicting the likehood of lymph node metastasis in early gastric patients. BMC Cancer. 2016; 16: 92.

22. Park H, Lee K, Yoo M et al. Mixed Carcinoma as an Independent Prognostic Factor in Submucosal Invasive Gastric Carcinoma. J Korean Med Sci. 2016; 31: 866-872.

23. Jagric T, Potrc $S$, Mis $K$ et al. CA19-9 serum levels predict micrometastases in patients with gastric cancer. Radiol Oncol. 2016; 50(2): 204-211. 
24. Tang $\mathrm{H}$, Hu J. A comparison of surgical procedures and postoperative cares for minimally invasive laparoscopic gastrectomy and open gastrectomy in gastric cancer. Int J Clin Exp Med. 2015; 8(7): 10321-10329.

25. Hur $\mathrm{H}$, Lee $\mathrm{H}$, Lee $\mathrm{H}$ et al. Efficacy of laparoscopic subtotal gastrectomy with $\mathrm{D} 2$ lymphadectomy for locally advanced gastric cancer: the protocol of the KLASS-02 multicenter randomized controlled clinical trial. BMC Cancer. 2015; 15: 355.

26. Lee $\mathrm{C}$, Jee $\mathrm{Y}$, Lee $\mathrm{J}$ et al. Length of negative resection margin does not affect local recurrence and survival in the patients with gastric cancer. World J Gastroenterol. 2014; 20(30): 10518-10524.

27. Huscher C, Mingoli A, Sgarzini G et al. Laparoscopic Versus Open Subtotal Gastrectomy for Distal Gastric Cancer: Five-Year Results of a Randomized Prospective Trial. Ann Surg. 2005; 241(2): 232-237.

28. Straatman J, Wielen N, Cuesta $M$ et al. Surgical techniques, open versus minimally invasive gastrectomy after chemotherapy(STOMACH trial): study protocol for a randomized controlled trial. Trials. 2015; 16: 123.

29. Degiuli M, Manzoni G, Leo A et al. Gastric cancer: Current status of lymph node dissection. World J Gastroenterol. 2016; 22(10): 2875-2893.

30. Białek A, Wiechowska-Kozłowska A, Pertkiewicz J et al. Endoscopic submucosal dissection for the treatment of neoplastic lesions in the gastrointestinal tract. World J Gastroenterol. 2013; 19(12): 1953-1961.

31. Hartgrink $\mathrm{H}$, Velde $\mathrm{C}$, Putter $\mathrm{H}$ et al. Extended Lymph Node Dissection for Gastric Cancer: Who May Benefit? Final Results of the Randomized Dutch Gastric Cancer Group Trial. J Clin Oncol. 2004; 22(11).

32. Kawamura Y, Satoh S, Umeki Y et al. Evaluation of the recurrence pattern of gastric cancer after laparoscopic gastrectomy with D2 lymphadenectomy. Springerplus. 2016; 5: 812.

33. Song J, Choi Y, An J et al. Short-Term Outcomes of Laparoscopic Total Gastrectomy Performed by a Single Surgeon Experienced in Open Gastrectomy: Review of Initial Experience. J Gastric Cancer. 2015; 15(3): 159-166.

34. Son S, Kim H. Minimally invasive surgery in gastric cancer. World J Gastroenterol. 2014; 20(39): 14132-14141.
35. Kataoka K, Katai H, Mizusawa J et al. Non-Randomized Confirmatory Trial of Laparoscopy-Assisted Total Gastrectomy and Proximal Gastrectomy with Nodal Dissection for Clinical Stage I Gastric Cancer: Japan Clinical Oncology Group Study JCOG1401. J Gastric Cancer. 2016; 16(2): 93-97.

36. Suda K, Nakauchi M, Inaba K et al. Minimally invasive surgery for upper gastrointestinal cancer: Our experience and review of the literature. World J Gastroenterol. 2016; 22(19): 4626-4637.

37. Zhang Y, Qi F, Jiang $Y$ et al. Long-term follow-up after laparoscopic versus open distal gastrectomy for advanced gastric cancer. Int J Clin Exp Med. 2015; 8(8): 13564-13570.

38. Sumer F, Kayaalp C, Karagul S. Laparoscopic Gastrectomy and Transvaginal Specimen Extraction in a Morbidly Obese Patient with Gastric Cancer. J Gastric Cancer. 2016; 16(1): 51-53.

39. Wang J, Zhang S, Zhang $\mathrm{N}$ et al. Laparoscopic gastrectomy versus open gastrectomy for elderly patients with gastric cancer: a systematic review and meta-analysis. World J Surg Oncol. 2016; 14: 90.

40. Wang W, Zhang X, Shen C et al. Laparoscopic versus Open Total Gastrectomy for Gastric Cancer: An Updated Meta-Analysis. PLoS One. 2014; 9(2).

Artykuł przyjęty do redakcji: 10.07.2017

Artykuł przyjęty do publikacji: 03.11.2017

Źródło finansowania: Praca nie jest finansowana z żadnego źródła. Konflikt interesów: Autorzy deklarują brak konfliktu interesów.

\author{
Adres do korespondencji: \\ Piotr Chmielewski \\ ul. Tytusa Chałubińskiego 6a \\ 50-368 Wrocław \\ tel. kom.: 693546294 \\ e-mail: piotr.chmielewski@umed.wroc.pl \\ Zakład Anatomii Prawidłowej, Katedra Morfologii i Embriologii Człowieka \\ Uniwersytet Medyczny im. Piastów Śląskich we Wrocławiu
}

